\title{
Range extension of Diclidurus scutatus (Chiroptera, Emballonuridae) to southwestern Amazonia
}

\author{
Roberto Leonan Morim NOVAES ${ }^{1 *}$, Vinícius Cardoso CLÁUDIO², Adriana Akemi KUNIY³ \\ 1 Universidade Federal do Rio de Janeiro, Instituto de Biologia. Av. Carlos Chagas Filho 373, CEP 21941-902, Rio de Janeiro, RJ, Brazil. \\ 2 Universidade Federal de São Carlos, Centro de Ciências Biológicas e da Saúde, Rodovia Washington Luiz, Km 235, CEP 13565-905, São Carlos, SP, Brazil. \\ 3 JGP Consultoria e Participaçōes Ltda., Rua Américo Brasiliense 615, CEP 04715-003, São Paulo, SP, Brazil. \\ * Corresponding author: robertoleonan@gmail.com
}

\section{ABSTRACT}

Diclidurus scutatus is an aerial insectivore bat endemic of South America and considered rare throughout its distribution range. We present the first record of this species in Rondônia State, northern Brazil, expanding its distribution more than 1000 $\mathrm{km}$ into southwestern Amazonia. Including this record, D. scutatus is known for 20 localities from eight countries (Brazil, Colombia, Ecuador, French Guiana, Guyana, Peru, Suriname, Venezuela), and two biomes_Amazonia and Atlantic Forest.

KEYWORDS: distribution, lesser ghost bat, western Amazon, Rondônia

\section{Extensão da distribuição de Diclidurus scutatus (Chiroptera, Emballonuridae) para o sudoeste da Amazônia}

\section{RESUMO}

Diclidurus scutatus é um morcego insetívoro aéreo, endêmico da América do Sul e considerado raro em toda sua área de distribuição. Apresentamos o primeiro registro dessa espécie para o estado de Rondônia, norte do Brasil, expandindo sua distribuição em mais de 1000 quilômetros para o sudoeste da Amazônia. Incluindo o presente registro, D. scutatus é conhecido para 20 localidades em oito países (Brasil, Colômbia, Equador, Guiana Francesa, Guiana, Peru, Suriname, Venezuela) e dois biomas-Amazônia e Mata Atlântica.

PALAVRAS-CHAVE: Amazônia ocidental, distribuição, morcego, Rondônia 
The determination of a taxon's distribution is important to understand evolutionary and biogeographic processes, and provides information about the ecology and natural history of a species (Whittaker et al. 2005). Studies that contribute to the knowledge of the distributional limits of a species, especially rare ones, are also important for conservation biology initiatives (Teixeira et al. 2014).

The bat genus Diclidurus Wied-Neuwied, 1820 has four species, all endemic to the Neotropics (Simmons 2005). They are insectivorous bats with fast flight ability that forage at great heights in the forest canopy, open areas and above water courses (Kalko et al. 1996; Lim et al. 1999). Diclidurus species are rare in inventories due to the difficulty in capturing the animals using traditional mist-net methodology, and most of their records come from manual capture, collection with firearms, and mist-nets placed in the forest canopy or near foraging areas, such as lampposts (Handley 1976; Dalponte and Aguiar 2009; Escobedo and Velazco 2012; Ferreira et al. 2013).

The lesser ghost bat, Diclidurus scutatus Peters, 1869, is an endemic bat from South America, with widespread occurrence in the Amazon and a single record for the Atlantic Forest in southeastern Brazil (Sodré and Uieda 2006; Escobedo and Velazco 2012). As conventional methods have small capture success for this species, the distribution limits of D. scutatus are not well established (Sampaio et al. 2016). We report the first record of D. scutatus in Rondônia State and present a distribution review of this species.

Bats were sampled between January and February 2014 in forest areas around the locality of Vila Tabajara, Machadinho D’Oeste Municipality, Rondônia State, Brazil (08º56'S, $62^{\circ} 03^{\prime} \mathrm{W}, 82 \mathrm{~m}$ ). Vila Tabajara is a small village on the margin of the Machado River. The local vegetation is classified as open ombrophilous forest, within the Amazonian domain (IBGE 2012).

On February 5, 2014 a group of bats, easily distinguished due to their white coloration, were seen foraging around a lamppost in an open area nearby the village. The capture of a D. scutatus non-reproductive adult female (Figure 1) happened around 01:45 am using a mist-net $(6 \times 3 \mathrm{~m}, 20$ $\mathrm{mm}$ mesh), which was manually launched on the foraging bats. This specimen was identified according to characters supported by the literature (Jones and Hood 1993; Lim and Engstrom 2001): general white coloration; unicolored ventral fur; forearm $54.2 \mathrm{~mm}$; greatest length of skull $15.0 \mathrm{~mm}$; large palatine foramina that is confluent with posterior palatal emargination; and no space between the premolars (Figure 2). The specimen was incorporated into the mammal collection of São Paulo University [Museu de Zoologia da Universidade de São Paulo] (MZUSP 35681).

With this record, D. scutatus has been recorded in 20 locations in eight South American countries, in Brazil,

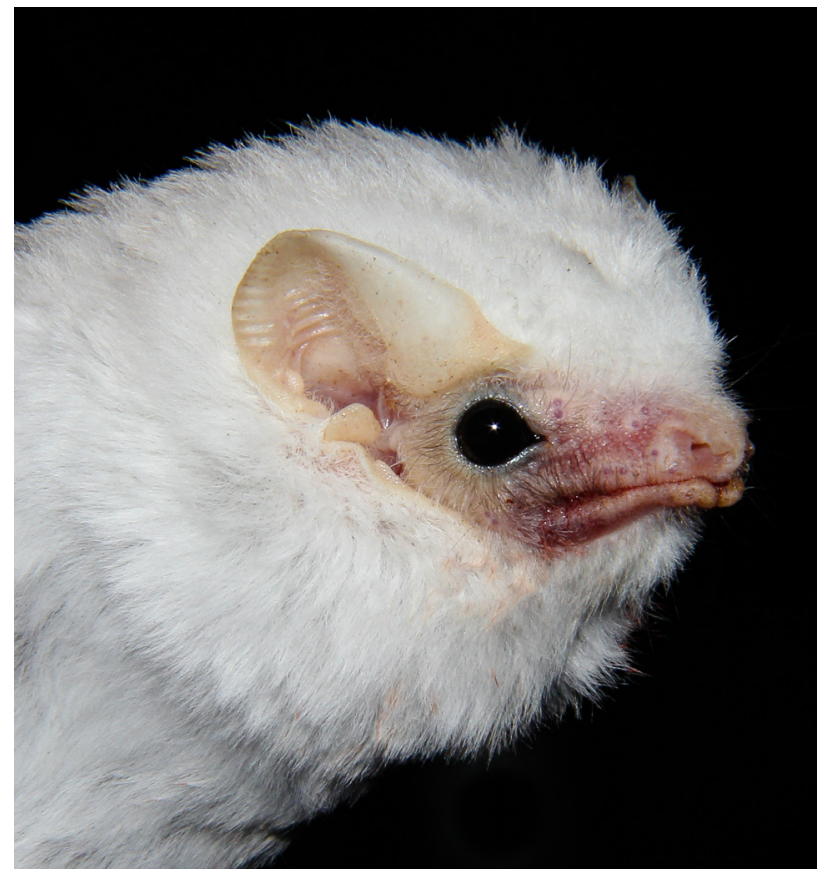

Figure 1. Specimen of Diclidurus scutatus (MZUSP 35681) from Machadinho D’Oeste, Rondônia, Brazil (Credit: Roberto Leonan Morim Novaes). This figure is in color in the electronic version.

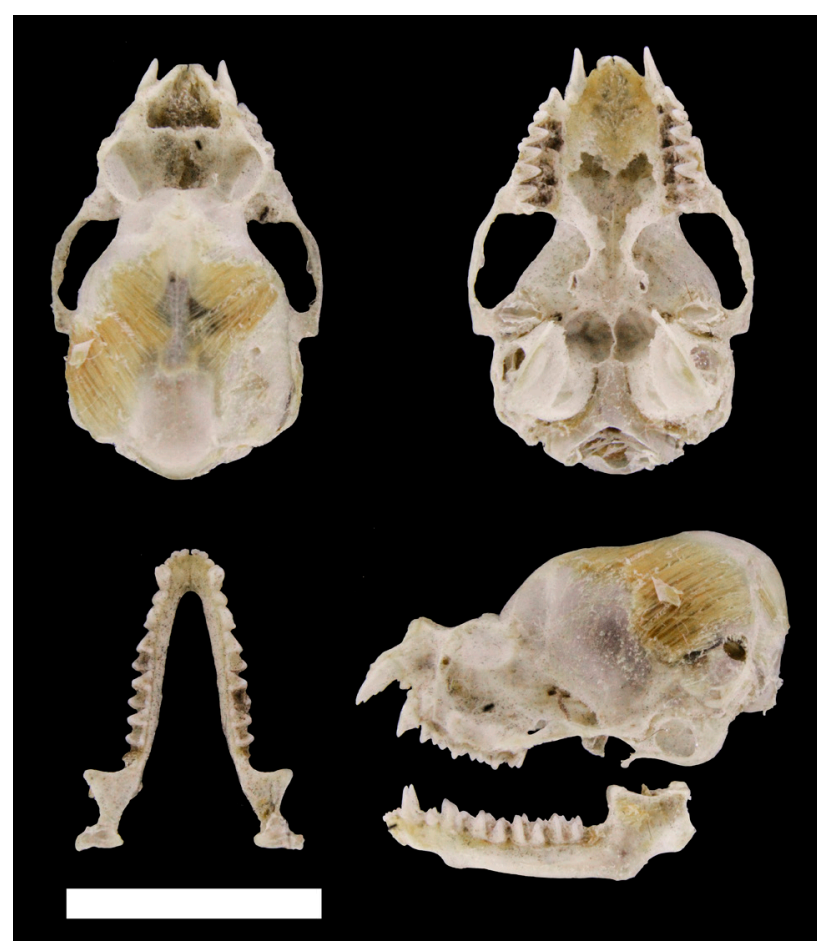

Figure 2. Skull (lateral, dorsal, and ventral profiles) and mandible (lateral and dorsal profiles) of Diclidurus scutatus (MZUSP 35681) from Machadinho D’Oeste, Rondônia, Brazil (Credit: José Eduardo Serrano Villavicencio). Scale bar $=10 \mathrm{~mm}$. This figure is in color in the electronic version. 
Colombia, Ecuador, French Guiana, Guyana, Peru, Suriname and Venezuela (Figure 3, Table 1). Geographical coordinates in Table 1 were recovered directly from the studies used in the distribution review or from the gazetteer available in Gardner (2008). Diclidurus scutatus has now been registered in five Brazilian states: one in the Atlantic Forest (Sáo Paulo) and four in the Amazon (Amapá, Amazonas, Pará and Rondônia). Our record from Rondônia represents the southernmost occurrenc of the species in the Amazon, extending its known distribution range by more than $1000 \mathrm{~km}$ in southwestern direction.
Diclidurus scutatus is known from only a few records but is unlikely to suffer a fast population decline, considering its wide distribution range and variety of environments occupied (Sampaio et al. 2016). The species is classified as of Least Concern in the IUCN Red List of Threatened Species (2017).

Our fieldwork efforts support the conclusion of Escobedo and Velazco (2012) in that the application of unusual sampling methodologies in bat surveys, such as active search and manual capture, canopy nets, and acoustic monitoring, are necessary to improve the knowledge about this species.

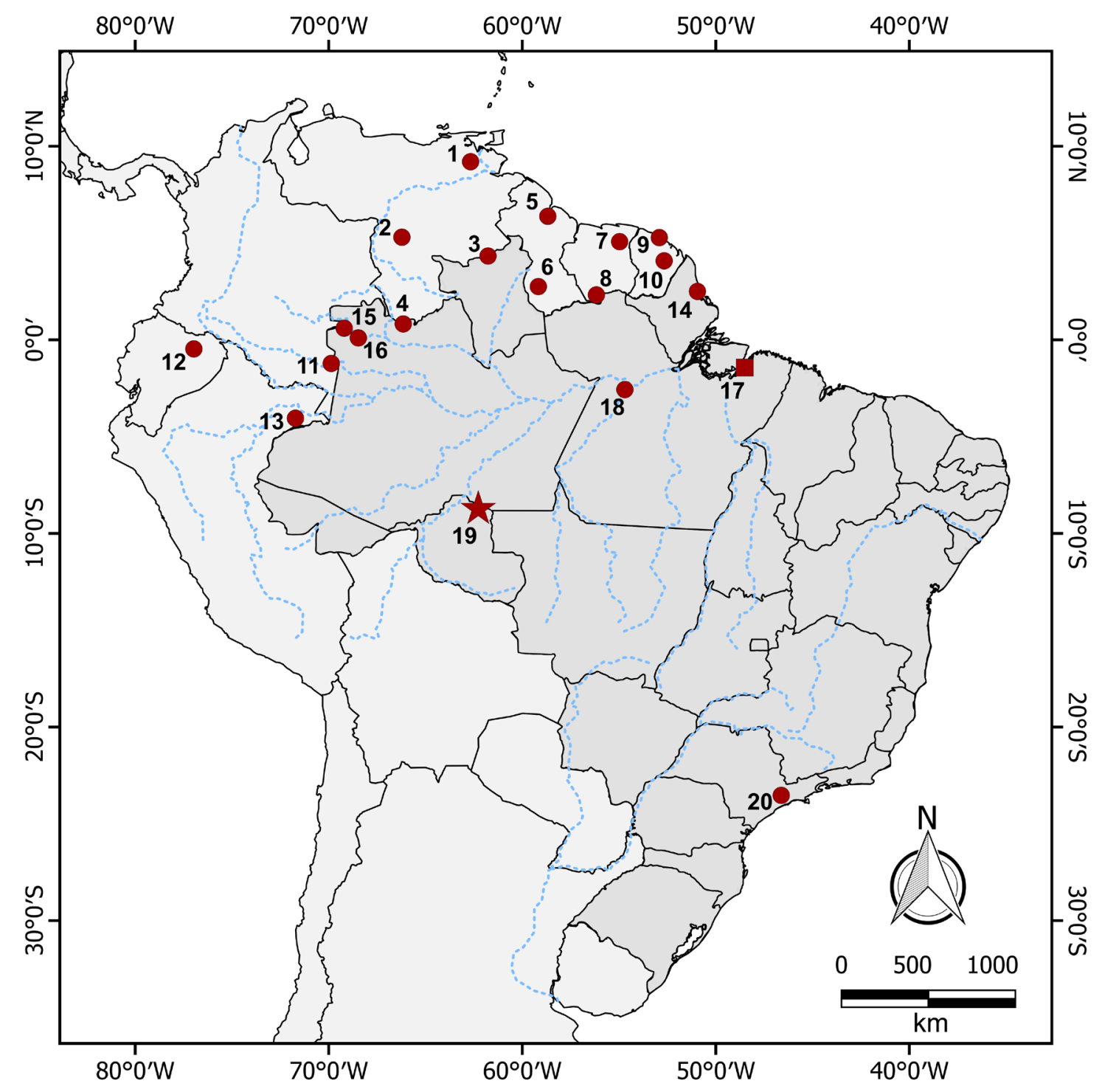

Figure 3. Distribution of Diclidurus scutatus (circles), including the type locality (square) and a new record for Machadinho D'Oeste, Rondônia, Brazil (star; this study). For more details, see Table 1. This figure is in color in the electronic version. 
Table 1. Locality records for the lesser ghost bat, Diclidurus scutatus.

\begin{tabular}{|c|c|c|c|}
\hline Map & Locality & Coordinates & Source \\
\hline 1 & Laguna Guasacónica, Monagas, Venezuela & $09^{\circ} 12^{\prime} \mathrm{N}, 62^{\circ} 40^{\prime} \mathrm{W}$ & Linares and Rivas (2004) \\
\hline 2 & Río Manapiare, San Juan, Amazonas, Venezuela & $05^{\circ} 18^{\prime} \mathrm{N}, 66^{0} 13^{\prime} \mathrm{W}$ & Handley (1976) \\
\hline 3 & Icabarú, Bolívar, Venezuela & $04^{\circ} 20^{\prime} \mathrm{N}, 61^{\circ} 46^{\prime} \mathrm{W}$ & Handley (1976) \\
\hline 4 & Cerro Neblina Base Camp, Amazonas, Venezuela & $00^{\circ} 49^{\prime} \mathrm{N}, 66^{\circ} 09^{\prime} \mathrm{W}$ & Gardner (1988) \\
\hline 5 & Cuyuni River, Kartabo Point, Cuyuni-Mazaruni, Guyana & $06^{0} 23^{\prime} \mathrm{N}, 58^{\circ} 41^{\prime} \mathrm{W}$ & Escobedo and Velazco (2012) \\
\hline 6 & Marurawaunawa Village, UpperTakutu-UpperEssequibo, Guyana & $02^{\circ} 45^{\prime} \mathrm{N}, 59^{\circ} 10^{\prime} \mathrm{W}$ & Escobedo and Velazco (2012) \\
\hline 7 & Brokopondo, Brokopondo, Suriname & $05^{0} 04^{\prime} \mathrm{N}, 54^{\circ} 58^{\prime} \mathrm{W}$ & Husson (1978) \\
\hline 8 & Alalapadu, Suriname & $02^{0} 19^{\prime} \mathrm{N}, 56^{0} 10^{\prime} \mathrm{W}$ & Escobedo and Velazco (2012) \\
\hline 9 & Paracou, Sinammary, French Guiana & $05^{\circ} 17^{\prime} \mathrm{N}, 52^{\circ} 55^{\prime} \mathrm{W}$ & Simmons and Voss (1998) \\
\hline 10 & Les Nouragues, Régina, French Guiana & $04^{\circ} 05^{\prime} \mathrm{N}, 52^{\circ} 40^{\prime} \mathrm{W}$ & Brosset and Charles-Dominique (1991) \\
\hline 11 & Lower Río Apaporis, Yay Gojes, Colombia & $01^{0} 13^{\prime} \mathrm{S}, 69^{\circ} 52^{\prime} \mathrm{W}$ & Escobedo and Velazco (2012) \\
\hline 12 & Coca, Orellana, Ecuador & $00^{\circ} 28^{\prime} \mathrm{S}, 76^{\circ} 58^{\prime} \mathrm{W}$ & Albuja (1999) \\
\hline 13 & Río Yavari, mouth of Lago Preto, Loreto, Peru & $04^{\circ} 03^{\prime} \mathrm{S}, 71^{\circ} 43^{\prime} \mathrm{W}$ & Escobedo and Velazco (2012) \\
\hline 14 & Colônia Torrão, Calçoene, Amapá, Brazil & $02^{\circ} 30^{\prime} \mathrm{N}, 50^{\circ} 57^{\prime} \mathrm{W}$ & Piccinini (1974) \\
\hline 15 & Rio Negro, Taracuá, Amazonas, Brazil & $00^{\circ} 06^{\prime} \mathrm{N}, 68^{\circ} 28^{\prime} \mathrm{W}$ & Vieira (1942) \\
\hline 16 & Rio Uaupés, Jauareté, Amazonas, Brazil & $00^{\circ} 36^{\prime} \mathrm{N}, 69^{\circ} 12^{\prime} \mathrm{W}$ & Piccinini (1974) \\
\hline 17 & Belém, Pará, Brazil (type locality) & $01^{\circ} 27^{\prime} \mathrm{S}, 48^{\circ} 29^{\prime} \mathrm{W}$ & Peters (1869) \\
\hline 18 & Rio Tapajós, Piquiatuaba, Santarém, Pará, Brazil & $02^{\circ} 34^{\prime} \mathrm{S}, 54^{\circ} 42^{\prime} \mathrm{W}$ & Escobedo and Velazco (2012) \\
\hline 19 & Vila Tabajara, Machadinho D’Oeste, Rondônia, Brazil & $08^{\circ} 56^{\prime} \mathrm{S}, 62^{\circ} 03^{\prime} \mathrm{W}$ & Present study \\
\hline 20 & São Paulo, São Paulo, Brazil & $23^{\circ} 32^{\prime} \mathrm{S}, 46^{0} 37^{\prime} \mathrm{W}$ & Sodré and Uieda (2006) \\
\hline
\end{tabular}

\section{ACKNOWLEDGEMENTS}

To the team of JGP Consultoria e Participaçôes Ltda. for the help in fieldwork; to Coordenação de Aperfeiçoamento de Pessoal de Nível Superior (CAPES) and Programa de Pós-Graduação em Biodiversidade e Biologia Evolutiva (Universidade Federal do Rio de Janeiro - UFRJ) for a master's scholarship for RLMN; to Programa de Pós-Graduaçáo em Conservação de Fauna (Universidade Federal de São Carlos - UFSCar) and Fundaçáo Parque Zoológico de São Paulo for a master's scholarship for VCC; to T.S. Teixeira and G. Jacob for the review of the manuscript. J.E.S. Villavicencio photographed the skull of the specimen.

\section{REFERENCES}

Albuja, V.L. 1999. Murciélagos del Ecuador. 2nd ed. Cicetrónica Cía, Quito, 288p.

Brosset, A.; Charles-Dominique, P. 1991. The bats from French Guiana: a taxonomic, faunistic and ecological approach. Mammalia, 54: 509-560.

Dalponte, J.C.; Aguiar, L.M.S. 2009. The first record of Diclidurus ingens Hernandez-Camacho, 1955 (Emballonuridae) in Central Brazil. Biota Neotropica, 9: 249-252.
Escobedo, M.; Velazco, P.M. 2012. First confirmed record for Peru of Diclidurus scutatus Peters, 1869 (Chiroptera: Emballonuridae). Check List, 8: 554-556.

Ferreira, A.P.; Melo, D.C.; Loures-Ribeiro, A. 2013. Diclidurus albus Wied-Neuwied, 1820 (Chiroptera: Emballonuridae): first record of the species in the state of Paraíba, Brazil. Check List, 9: 793-796.

Gardner, A.L. 1988. The mammals of Parque Nacional Serranía de la Neblina, Territorio Federal Amazonas, Venezuela. In: BrewerCarias, C. (Ed.). Cerro de La Neblina: resultados de la expedición 1983-1987. Editorial Sucre, Caracas, p.695-765.

Gardner, A.L. 2008 [2007]. Mammals of South America, volume 1. Marsupials, xenarthrans, shrews, andbats. University of Chicago Press, Chicago and London, 690p.

Handley, C.O., Jr. 1976. Mammals of the Smithsonian Venezuelan Project. Brigham Young University Science Bulletin, Biological Series, 20: 1-89.

Hood, C.; Gardner, A.L. 2008 [2007]. Family Emballonuridae Gervais, 1856. In: Gardner, A.L. (Ed.). Mammals of South America, volume 1. Marsupials, xenarthrans, shrews, and bats. University of Chicago Press, Chicago and London, p.188-207.

Husson, A.M. 1978. The mammals of Suriname. Zoölogische Monographieën van het Rijksmuseum van Natuurlijke Historie, E. J. Brill, Leiden, 569p. 
IBGE. 2012. Manual técnico da vegetação brasileira. Instituto Brasileiro de Geografia e Estatística, Brasília, 275p.

IUCN Red List of Threatened Species, The. 2017. Version 2017-1. (www.iucnredlist.org). Accessed on 10 July 2017.

Jones, J.; Hood, C. 1993. Synopsis of South American bats of the family Emballonuridae. Occasional Papers of Museum of the Texas Tech University, 155: 1-32.

Kalko, E.K.V.; Handley, C.O.; Handley, D. 1996. Organization, diversity, and long-term dynamics of a neotropical bat community. In: Cody, M.L.; Smallwood, J.A. (Eds.). Long-term studies of vertebrate communities. Academic Press, New York, p.503-553.

Lim, B.K.; Engstrom, M.D. 2001. Species diversity of bats (Mammalia: Chiroptera) in Iwokrama Forest, Guyana, and the Guianan subregion: implications for conservation. Biodiversity and Conservation, 10: 613-657.

Lim, B.K.; Engstrom, M.D.; Timm, R.M.; Anderson, R.P.; Watson, L.C. 1999. First records of 10 bat species in Guyana and comments on diversity of bats in Iwokrama Forest. Acta Chiropterologica, 1: 179-190.

Linares, O.J.; Rivas, B. 2004. Mamíferos del sistema deltaico (delta de Orinoco-golfo de Paria), Venezuela. Memorias de La Fundación La Salle de Ciencias Naturales, 159/160: 27-104.

Peters, W. 1869. Bemerkungen über neue oder weniger bekannte Flederthiere, besonder des Pariser Museums. Monatsberichte der Königlichen Preussischen Akademie der Wissenschaften zu Berlin, 1869: 391-406.

Piccinini, R.S. 1974. Lista provisória dos quirópteros da coleção do Museu Paraense Emílio Goeldi (Chiroptera). Boletim do Museu Paraense Emílio Goeldi, Série Zoologia, 77: 1-32.
Sampaio, E.; Lim, B.; Peters, S. 2016. Diclidurus scutatus. The IUCN Red List of Threatened Species (http://www.iucnredlist.org/ details/6564/0). Accessed on 06 October 2016.

Simmons, N.B. 2005. Order Chiroptera. In: Wilson, D.E.; Reeder, D.M. (Eds.). Mammal species of the world: a taxonomic and geographic reference. Johns Hopkins University Press, Baltimore, p.312-529.

Simmons, N.B.; Voss, R.S. 1998. The mammals of Paracou, French Guiana: a neotropical low land rainforest fauna, Part 1. Bats. Bulletin of the American Museum of Natural History, 237: 1-219.

Sodré, M.M.; Uieda, W. 2006. First record of the ghost bat Diclidurus scutatus Peters (Mammalia, Chiroptera, Emballonuridae) in São Paulo city, Brazil. Revista Brasileira de Zoologia, 23: 897-898.

Teixeira, T.S.M.; Weber, M.M.; Dias, D.; Lorini, M.L.; Esbérard, C.E.L.; Novaes, R.L.M.; Cerqueira, R.; Vale, M.M. 2014. Combining environmental suitability and habitat connectivity to map rare or Data Deficient species in the Tropics. Journal for Nature Conservation, 22: 384-390.

Vieira, C.O.C. 1942. Ensaio monográfico sobre os quirópteros do Brasil. Arquivos de Zoologia do Estado de São Paulo, 3: 219-471.

Whittaker, R.; Araújo, M.B.; Jepson, P.; Ladle, R.J.; Watson, J.E.M.; Willis, K.J. 2005. Conservation biogeography: assessment and prospect. Diversity and Distribution, 11: 3-23.

Received: 01/03/2017

Accepted: 23/07/2017 
